\title{
Correction to: HLA-F*01:01 presents peptides with N-terminal flexibility and a preferred length of 16 residues
}

\author{
Gia-Gia T. Hò ${ }^{1} \cdot$ Funmilola J. Heinen ${ }^{1} \cdot$ Trevor Huyton $^{2} \cdot$ Rainer Blasczyk $^{1} \cdot$ Christina Bade-Döding $^{1}$
}

Published online: 24 April 2019

(C) Springer-Verlag GmbH Germany, part of Springer Nature 2019

\section{Correction to: Immunogenetics}

$$
\text { https://doi.org/10.1007/s00251-019-01112-1 }
$$

The original version of this article contained errors. The Article Title, Figures 1 and 3, and Electronic Supplementary Materials were incorrectly shown in the wrong version. The original article has been corrected.

Publisher's note Springer Nature remains neutral with regard to jurisdictional claims in published maps and institutional affiliations.

The online version of the original article can be found at https://doi.org/ 10.1007/s00251-019-01112-1

Christina Bade-Döding

bade-doeding.christina@mh-hannover.de

1 Institute for Transfusion Medicine, Hannover Medical School,

Carl-Neuberg-Str. 1, 30625 Hannover, Germany

2 Department of Cellular Logistics, Max Planck Institute for

Biophysical Chemistry, AmFassberg 11, 37077 Göttingen, Germany 